\title{
Authority of the Village Head in Efforts to Settle Land Disputes Based on Law Number 6 Year 2014
}

\author{
Tika Puspa Lestari", Ilwan ${ }^{* *}$, RR. Cahyowati** \\ *Postgraduate program Legal Study and Notaries, Mataram University, Indonesia \\ *** Lecture of Law Faculty Mataram University, Indonesia
}

\begin{abstract}
:
The purpose of this study was to find out the procedure for land dispute resolution carried out by the Village Head, to find out the basis of authority of the Village Head in land dispute resolution efforts based on Law Number 6 of 2014 concerning Villages and to find out the legal strength of land dispute resolution. This type of research is normative legal research. The theory used in this study is the theory of dispute resolution, the theory of authority and the theory of legal certainty. The approach method used is the legislative approach, case approach, and conceptual approach. Based on the results of the study that the procedure for land dispute resolution carried out by the Village Head was carried out in several stages, namely: 1. complaints; 2. summons of disputing parties; 3. the process of deliberation; and 4. formulating the results of the agreement in the form of a Joint Peace Letter. The authority of the Village Head in an effort to resolve land disputes is Article 26 of Law Number 6 Year 2014 concerning Villages and Law Number 30 Year 2014 concerning Government Administration. The power of land dispute resolution law carried out by the village head in the form of a Peace Letter on land disputes made by the Village Head based on what has been agreed upon by the disputing parties, it can be said that what is stated in the Peace Letter is valid and applies as a Law for those who make it, in this case the parties to the dispute. The agreements are irrevocable for reasons which are sufficient by law.
\end{abstract}

Keywords: authority, village head, land dispute resolution

\section{Introduction}

The Village Government is a subsystem of the Government Operator, so that the Village has the authority to regulate and manage the interests of its people. The village as an area or the smallest area led by a village head who is chosen from and by the villagers who has the right to vote, be appointed or confirmed by the regent or appointed official.

With the division of authority between the center and the regions, the authority relationship is stipulated as stipulated in the 1945 Constitution Article 18 A paragraph (1), namely the relationship of authority between the Central Government and Provincial, Regency and City Governments Regulated by Law with regard to specificity and regional diversity.

The Law of the Republic of Indonesia Number 6 of 2014 concerning Villages explains that Villages have origin rights and traditional rights to regulate and play a role in realizing the ideals of independence based on the 1945 Constitution of the Republic of Indonesia.

In the course of the constitution of the Republic of Indonesia, the Village has developed in various forms so that it needs to be protected and empowered in order to be strong, advanced, independent and democratic so as to create a strong foundation in implementing government and development towards a just, prosperous and prosperous society. Villages in the structure and procedures for organizing government and development need to be regulated separately by law. consists of:

In implementing the government, the Village Head is assisted by the village apparatus, which 1. Staff elements, namely elements of service, village secretariat and or administration; 
2. The executive element, namely the field technical implementing elements, village civil service elements and security;

3. Regional elements, namely servants in the territory of the village head, hamlet head, whose number and designation are in accordance with the needs and socio-cultural conditions of the local community. ${ }^{1}$

Considering the stronger position, authority and village finance, the implementation of village governance is expected to be more accountable, supported by a system of supervision and balance between the village government and village institutions.

The formulation of the problem used is: a. What is the procedure for resolving land disputes carried out by the Village Head? b. What is the basis of the authority of the Village Head in an effort to resolve land disputes? c. What are the legal strengths of land dispute resolution carried out by the village head?

Based on the formulation of the problem described, the purpose of this study is a. To find out procedures for resolving land disputes carried out by the Village Head, $b$. To find out the basis of authority of the Village Head in efforts to resolve land disputes, c. To find out the legal strength of land dispute resolution by the Village Head.

Research this thesis uses Normative Law research using the Legislation approach, conceptual approach and Case Approach. The legal material collection technique used in this study is the study of documents using analysis of grammatical interpretation and systematic interpretation as an analysis of legal material.

\section{Result And Discussion}

\subsection{Procedures for Settling Land Disputes Performed by the Village Head}

\subsubsection{Overview of the Settlement of Land Disputes}

The laws that apply in society are not only written laws, but also laws that grow in society. Society is a form of shared life, which citizens live together for a long period of time, resulting in culture. ${ }^{2}$ In essence, land cases are conflicts of interest in the land sector between individuals and individuals; individuals with legal entities; legal entities with legal entities and so on. In order to obtain legal certainty as mandated in the LoGA, the said land case can be given a response/reaction/resolution to those concerned (the public and the government).

Settlement is the process, action, how to complete. Completion means making it easier, making ends, clearing or deciding, arranging, reconciling (disputes or quarrels), or arranging something to be good. ${ }^{3}$ The land dispute resolution process can generally be done through a court forum (litigation), however, it can also be resolved through an alternative dispute resolution framework, such as through the institutions authorized by the Indonesian National Arbitration Agency (BANI), then through Negotiation, Mediation, Conciliation, Mediation, besides that it can also be through the National Land Agency.

Law Number 30 of 1999 concerning Arbitration and Alternative Dispute Resolution is one of the laws governing the settlement of disputes or differences of opinion between parties in a certain legal relationship that has entered into an arbitration agreement which expressly states that all disputes or differences of opinion arising from the legal relationship will be settled by arbitration or through an alternative dispute resolution. 4

The way to settle disputes can be done through courts, ADR and through customary institutions. The method of resolving disputes regulated in the Civil Procedure Code, namely through a court, meanwhile, the method of dispute resolution regulated by Law Number 30 of 1999 concerning Arbitration and Alternative Dispute Resolution, namely alternative dispute resolution (ADR). There are five ways to resolve disputes through ADR, which include:
a. Consultation
b. Negotiation
c. mediation
d. Conciliation; or

\footnotetext{
${ }^{1}$ Article 8 paragraph (2) Decree of the Minister of Home Affairs Number 64 of 1998.

${ }^{2}$ Soerjono Soekanto, 1983, Hukum Adat Indonesia, PT Raja Grafindo Perkasa, Jakarta, p. 91.

${ }^{3}$ Departemen Pendidikan dan Kebudayaan, Kamus Besar Bahasa Indonesia, Jakarta: Balai Pustaka, 1989, p. 801.

${ }^{4}$ Article 2 of Act Number 30 of 1999 concerning Arbitration and Alternative Dispute Resolution.
} 
e. Expert judgment. ${ }^{5}$

Meanwhile, in Law Number 7 of 2012 concerning the handling of social conflicts, the way to resolve disputes in the community is carried out peacefully. Peaceful dispute resolution is a way to end disputes or conflicts that occur in the community using deliberation so that both parties do not feel disadvantaged, they both accept each other. Meanwhile, institutions that are authorized to resolve conflicts include:
a. Government;
b. Local government;
c. Customary Institution; and / or
d. Social Institution; and
e. The task force for resolving social conflicts. ${ }^{6}$

From the description above, it can be concluded that there are three patterns of dispute resolution in the community, which include:
a. Court
b. ADR; and
c. Peace.

In addition to the three methods above, it is also known how to resolve disputes through traditional institutions and values that develop in the community. Customary institutions and values that live in society in Indonesia are local because each ethnic or region has traditional institutions and values that are different from each other. ${ }^{7}$

The way of resolving customary disputes by the village head as the village leader and also as a judge of village peace is similar to "mediator" where the village head acts as a neutral party that helps the two parties to the dispute in the dispute resolution process through negotiations or consensus. In this case the village head does not have the authority to decide. The Village Head only assists the disputing parties in finding a solution that is acceptable to the parties.

\subsubsection{Procedure for Settling Land Disputes by the Village Head}

The procedure for land dispute resolution carried out by the Head is carried out in several stages, namely:

a. Complaint

The initial stage of the dispute settlement procedure in the Village is a complaint from one of the parties to the dispute. The aim is to convey information to the Village Head regarding the problems at hand. Complaints made in the village are mostly carried out verbally by the disputing parties.

b. Calling of Disputing Parties

At this stage, the Head of the Village with assistance from the Village Head of Kasi then calls the complainant, the party to the dispute. While waiting for the arrival of the complainant, the complainant / reporter is welcome to wait at the meeting hall in the Village. Not only was the party complained, but the Village Chief also invited the local hamlet head to attend the land dispute resolution process, the hamlet chief knew that his citizens were in dispute and were asked to be a witness in the land dispute resolution process. Whereas the calling of the disputing parties is carried out to bring together all the disputing parties to hear from each party regarding the issue being disputed.

c. Deliberation Process

Settlement of land disputes in the village is always done by consensus. Settlement of land disputes in this way is considered the most suitable and in accordance with the national cultural values of a democratic Indonesia. Deliberation means discussing and resolving together a problem with the intention to reach consensus or agreement. In other words, deliberation and consensus is carried out by means of collective bargaining to solve problems, in order to reach decisions and collective agreements that will be jointly implemented.

\footnotetext{
${ }^{5}$ Salim HS dan Erlies Septiana Nurbani, Penerapan Teori Hukum Pada Penelitian Tesis dan Disertasi, Jakarta: PT RajaGrafindo Persada, 2017, p. 142.

${ }^{6}$ Article 40 of Law Number 7 of 2012 concerning Handling Social Conflict.

${ }^{7}$ Ibid, p. 143.
} 
The process of deliberation is usually held at the meeting hall at the Village Office. The Village Head explained that in the deliberation process carried out in the Village, the parties may come accompanied by other parties, but the parties accompanying them were not permitted to interfere in the ongoing deliberation process. This means that, in addition to the disputing parties, parties present at the deliberation process may only witness the process of the deliberation process, but are not allowed to issue their opinions, unless asked by the Village Head to provide information.

d. Formulation of Agreement Results in the Form of a Peace Letter

This joint peace letter is issued if an agreement has been desired jointly by the parties to the dispute. This joint peace letter was made with the aim that the things agreed upon by the parties can be carried out properly. The results of a joint agreement were confirmed in a joint peace letter on land disputes.

In Article 1851 the Civil Code states that: ${ }^{8}$

"Peace is an agreement whereby both parties, by surrendering, promising or holding an item, end a case that is dependent or prevents the occurrence of a case. The agreement is not valid but if it is written."

In the Civil Code in Article 1851 peace has the following elements: ${ }^{9}$

a) There is agreement between the parties

The agreement of the parties must be considered valid if it fulfills the elements of the agreement stipulated in Article 1320 of the Civil Code while the agreement must be in accordance with the provisions of Article 1321 of the Civil Code which states that no agreement or legal agreement is given because of:

1) Oversight;

2) Coercion;

3) Fraud.

Furthermore Article 1859 of the Civil Code states that a peace can be canceled if an error has occurred regarding the person or the subject of the dispute. He can cancel in any case where fraud or coercion has been done.

b) The contents of the agreement constitute an agreement to do something, Article 1851 of the Civil Code limits what legal actions are allowed. These restrictions include:

1) To give up an item;

2) Delivering something;

3) Hold an item.

c) Both parties agreed to end the dispute

Article 1851 of the Civil Code also says that peace can be carried out on existing cases both those that are running in the court and those that will be brought to court.

d) The dispute is being examined or to prevent a case or dispute from arising. Basically anyone can be the subject of the peace agreement as stipulated in Article 1852 of the Civil Code which reads:

"To establish a peace requires that a person has the power to give up his rights to the things contained in that peace. Trustees and officers cannot hold a peace other than if they act according to the provisions of the fifteenth and seventeenth chapters of the first book of this Law. Regional heads acting as such, as well as public institutions cannot make a peace by heeding the programs stipulated in legislation concerning them. "10

\subsection{Basic Authority of the Village Head in Efforts to Resolve Land Disputes}

\subsubsection{Village government}

Villages or other names have existed before the Unitary State of the Republic of Indonesia. As proof of its existence, Explanation of Article 18 of the 1945 Constitution of the Republic of Indonesia (before the amendment) states that "In the territory of the Indonesian Negata there are approximately 250" Zelfbesturende landschappen "and" Volksgemeenschappen", such as villages in Java and Bali, Nagari in Minangkabau, hamlets and clans in Palembang, and so on. These regions have an original structure and can

\footnotetext{
${ }^{8}$ R. Subekti dan R. Tjitrosudjibjo, Kitab Undang Undang Hukum Perdata, (a) Jakarta : Pradnya Paramita, 2003, Article 1851.

${ }^{9}$ Ibid, Article 1851

${ }^{10}$ Ibid, Article 1852
} 
therefore be considered as special areas. The Republic of Indonesia respects the position of these special regions and all state regulations concerning these regions in view of the rights to the origin of the region. "

In the history of village regulation, a number of regulations concerning the Village have been established, namely Law Number 22 of 1948 concerning the Principles of Regional Government, Law Number 1 concerning the Principles of Regional Government, Law Number 18 of 1965 concerning Principles of Regional Government, Law Number 19 of 1965 concerning Desa Praja as a Transitional Form to Accelerate the Realization of Level III Regions in the Entire Territory of the Republic of Indonesia, Law Number 5 Year 1974 concerning the Principles of Regional Government, Law Number 5 of 1979 concerning Village Government, Law Number 22 of 1999 concerning Regional Government, and finally by Law Number 32 of 2004 concerning Regional Government. ${ }^{11}$

In its implementation, the regulation regarding the Village has not been able to accommodate all the interests and needs of the Village community which according to the Regulation of the Head of the Central Bureau of Statistics Number 66 of 2016 concerning the 2016 Statistics Code and Work Areas stated that a number of villages in Indonesia are 82,030. While according to the Minister of Home Affairs Regulation No. 56 of 2015 concerning the Code and data on the administrative administration area, it is stated that the number of villages or Village in Indonesia is 83,184 (74,754 villages $+8,430$ Village. In addition, the implementation of village regulations has not been in line with the times, especially among others concerning the position of indigenous peoples, democratization, diversity, community participation, as well as progress and equitable development so as to create disparity between regions, poverty, and socio-cultural problems that can disrupt the integrity of the Unitary State of the Republic of Indonesia.

The Village Regulation was determined by the Village Head after being discussed and agreed upon with the Village Consultative Body as a legal and policy framework in the implementation of Village Government and Village Development. As a political product, Village Regulations are processed democratically and participatively, namely the drafting process includes the participation of the village community. The Village Community has the right to propose or provide input to the Village Head and the Village Consultative Body in the process of drafting Village Regulations.

Village regulations that regulate village authority based on local origin and authority scale Village implementation is overseen by the village community and the Village Consultative Body. It is intended that the implementation of the Deen Regulation can always be monitored continuously by the residents of the local village community considering that the Village Regulation is set for the benefit of the Village community.

The Village Head is elected directly by and from the Village residents of the Republic of Indonesia who fulfill the requirements with a term of office of 6 (six) years from the date of inauguration. The Village Head can hold a maximum of 3 (three) times in a row or not consecutively. While filling in the position and tenure of the Customary Village Chief applies the provisions of customary law in the Adat Village insofar as they are still alive and in accordance with the development of the community and the principles of the Unitary State of the Republic of Indonesia stipulated in the City Regulations.

The village has a village income source consisting of Village original income, regional tax sharing and Regency/City regional retribution, part of the central and regional financial balance funds received by the Regency/City, budget allocation from the State Budget and Expenditure, financial assistance from Provincial Revenue and Expenditure Budget and Regency/City Regional Revenue and Expenditure Budget, as well as grants and donations that are not binding on third parties.

Village development aims to improve the welfare of the village community and the quality of human life and poverty reduction through the provision of basic needs, development of facilities and infrastructure, development of local economic potential, and sustainable use of natural and environmental resources. For this reason, this Law uses 2 (two) approaches, namely "Village building" and "Village building" which are integrated in Village Development planning.

\subsubsection{The authority of the village head in an effort to resolve land disputes}

${ }^{11}$ Ibid, p. 68 
The Village Head as the main role in using and controlling decisions on policies in resolving disputes certainly has accountability for the legal decisions he does. In administrative theory, authority cannot be separated from obligations and responsibilities.

As Article 26 Paragraph (1) the head of the village is tasked with organizing the Village Government, implementing Village Development, Village Community Development, and empowering the Village community. While paragraph (2) in carrying out the tasks referred to in paragraph (1), the Village Head is authorized:

a. The Village Head is the main role in using and controlling decisions regarding kebia. lead the implementation of the Village Government;

b. Appoint and dismiss village officials;

c. Holding the power of Village Finance and Asset management;

d. Establish Village Regulations;

e. Establish Village Revenue and Expenditure Budget;

f. Fostering the life of the village community;

g. Fostering peace and order in the village community;

h. Fostering and improving the village economy and integrating it to achieve a productive scale economy for the greatest prosperity of the village community;

i. Developing village opinion sources;

j. Propose and accept the delegation of part of the country's wealth to improve the welfare of rural communities;

k. Developing the socio-cultural life of the village community;

1. Utilizing appropriate technology;

m. Coordinate Village Development in a participatory manner;

n. Represent the village inside and outside the court or appoint a legal counsel to represent it according to the provisions of the legislation; and

o. Carry out other authorities in accordance with the provisions of the legislation.

p. Will in resolving disputes, of course have responsibility for the legal decisions that it does. In administrative theory, authority cannot be separated from obligations and responsibilities.

q. As Article 26 Paragraph (1) the head of the village is tasked with organizing the Village Government, implementing Village Development, Village Community Development, and empowering the Village community. while paragraph (2) in carrying out the tasks referred to in paragraph (1), the Village Head is authorized:

In Article 6 of Law Number 30 of 2016 affirms that:

1. Government officials have the right to use the authority to make decisions and / or actions;

2. The rights referred to in paragraph (1) include:

a. Implementing the authority that is owned based on the provisions of the legislation and AUPB

b. Organize government activities based on the authority possessed;

c. Determine written or electronic decisions and / or determine actions;

d. Publish or not publish, change, replace, revoke, postpone, and / or cancel decisions and / or actions;

e. Use Discretion according to its purpose;

f. Delegate and provide Mandates to other Government Officials in accordance with the provisions of legislation;

g. Appoint daily executors or executors to carry out their duties if definitive officials obstruct;

h. Issuing licenses, dispensations, and / or concessions in accordance with statutory provisions;

i. Obtain legal protection and security guarantees in carrying out their duties;

j. Obtain legal assistance in carrying out their duties;

k. Resolve the Authority Dispute in the environment or territory of its authority;

1. Complete the Administrative Efforts submitted by the community for the Decisions and / or Actions made by them; and

m. Impose administrative sanctions on subordinates who commit violations as stipulated in this Act.

\subsection{Legal Strengths of Settling Land Disputes by the Village Head}


To ensure the existence of legal certainty, it is necessary to have strict law enforcement indiscriminately. Law enforcement for a Court Decision that has a permanent legal force is one of which is to carry out executions based on decisions that have executorial power as stated in the head of "FOR JUSTICE BASED ON THE ALMIGHTY GOD" Decision. This is in accordance with the principle of administering judicial power as stipulated in article 2 paragraph (1) of Law No. 48 of 2009 concerning Judicial Power.

The legal agreement carried out by the Village Head here is defined as an agreement reached by the parties with the help of the Village Head to resolve and end the dispute. In the Indonesian legal system agreement between consensus agreements outside the court is an agreement that only binds the parties and denial of agreed conditions is a violation of the agreement.

Peace Letter on land disputes made by the Village Head based on what has been agreed upon by the parties to the dispute when viewed from Article 1338 BW, it can be said that what is stated in the Peace Letter is valid and applies to those who make it, in terms of this is the party to the dispute. The agreements are irrevocable for reasons which are sufficient by law. Agreements must be carried out in good faith. However, when viewed from the strength of the proof of the Peace Letter, there is still a possibility that problems will arise again later on because the Peace Letter only includes a deed under the hand.

A letter of peace can be a perfect proof if the signature and contents of the letter are recognized by the parties who made it. So in this case the key to the strength of proof of the letter is that the parties making the letter acknowledge the signature and the contents of the letter, so that it is possible for the parties to deny it later. This is as stated in Article $1875 \mathrm{BW}$ which states:

"An article under the hand that is acknowledged by the person to whom it is intended to be used, or which according to the law is regarded as recognized, gives to the people who sign it and their heirs and those who get the rights rather than they are perfect proof such as an authentic deed, and so do the provisions of Article 1871 for that article. "

\section{Conclusion And Recomendation}

\subsection{Conclusion}

Based on the description that the author has described above, a conclusion can be drawn as follows:

1. The procedure for land dispute resolution carried out by the Village Head is carried out in several stages, namely: a. complaint; b. summons of parties to the dispute; c. deliberation process; and D. formulation of agreement results in the form of a Joint Peace Letter.

2. The authority of the Village Head in an effort to resolve land disputes is Article 26 of Law Number 6 Year 2014 concerning Villages and Law Number 30 Year 2014 concerning Government Administration.

3. The power of land dispute resolution law carried out by the village head in the form of a Peace Letter on land disputes made by the Village Head based on what has been agreed upon by the disputing parties, it can be said that what is stated in the Peace Letter is valid and applies as a Law for those who make it, in this case the parties to the dispute. The agreements are irrevocable for reasons which are sufficient by law. Agreements must be carried out in good faith. However, when viewed from the strength of the proof of the Peace Letter, there is still a possibility that problems will arise again later on because the Peace Letter only includes a deed under the hand.

\subsection{Recommendation}

Based on the research results above, the author would like to give the following suggestions:

1. There is a need for an Act which states explicitly that the Village Head has authority in resolving land disputes that occur in his area. This is intended so that the Village Head has a foothold in resolving disputes that occur in his area so that a peaceful and prosperous society is realized. Similar problems may arise later on, so an agreement on peace over land disputes should be made in the form of authentic deeds because authentic deeds have perfect evidentiary powers and do not require additional evidence.

2. That for the village government, especially the Village Head who wants to decide disputes or cases in the land sector, related to land disputes, it must be fair in deciding a case, and for the community in dispute must be based in good faith so that the problem does not continue to the judicial institution. 


\section{References}

[1] R. Subekti dan R. Tjitrosudjibjo. 2003. Kitab Undang Undang Hukum Perdata. (a) Jakarta: Pradnya Paramita.

[2] Salim HS and Erlies Septiana Nurbani. 2017. Penerapan Teori Hukum Pada Penelitian Tesis dan Disertasi. Jakarta: PT RajaGrafindo Persada.

[3] Soerjono, Soekanto. 1983. Hukum Adat Indonesia. Jakarta: PT Raja Grafindo Perkasa.

[4] Departemen Pendidikan dan Kebudayaan. 1989. Kamus Besar Bahasa Indonesia. Jakarta: Balai Pustaka.

[5] Law Number 30 of 1999 concerning Arbitration and Alternative Dispute Resolution.

[6] Decree of the Minister of Home Affairs Number 64 of 1998. 